\title{
The Practice Teaching Reform and Exploration of Accounting Profession in Colleges and Universities*
}

\author{
Jianghong YE
}

School of Economics \& Management, Beijing Institute of Petrochemical Technology, Beijing, China (yejianghong@bipt.edu.cn)

Abstract-As everyone knows, accounting is a very practical subject. It's important to cultivating the practice ability of students in higher education. The paper discussed the problems existed in the current accounting practice. Combined with the practical course system in author's college, suggested a few solutions in accounting practice teaching reform and implementation.

Keywords-Accounting Profession, Practice Teaching, Reform

\section{普通高等院校会计专业实践教学改革与探索}

\author{
叶江虹 \\ 北京石油化工学院经济管理学院, 北京, 中国
}

摘 要 众所周知, 会计学科是一门实践性很强的应用型学科, 培养学生的实践能力对于高校人才培养来说至关重要。本文指出 了目前会计专业实践教学中存在的问题, 结合作者所在院校会计专业实践教学体系的构建, 阐述了会计实践教学方面的改革方式与 实施保障。

关键词 会计专业, 实践教学, 改革

\section{1. 引言}

国民经济各个行业都需要财务会计人员, 因此, 在人 才招聘职位需求排行榜上, 财会岗位一直处于较靠前的位 置。既然各行各业都具有大量会计人员岗位的可能性, 那 么, 这是否意味着会计专业毕业生的就业前景必然是一片 光明呢? 事实并非如此。由于国家的经济发展, 持续热门 的财经类专业, 特别是会计专业, 目前的就业总体状况为 供大于求和结构性失衡。具体来讲, 各地高级财务会计管 理人才短缺, 普通的财务会计人员供过于求。作为刚刚走 出校门的会计专业学生, 拥有的是理论知识, 不具备的是 实际工作能力和实际操作能力。而大部分企业在招聘人才 时, 要求员工到岗就能工作。学生岗位工作能力, 决定其 市场就业竞争能力。因此加何提高会计实践教学水平, 实 现从高校教学到用人单位需要的有效对接就成为各高校研 究的重要议题。

*北京石油化工学院重点教改项目支持（项目编号：ZD20130401）

\section{2. 目前会计学专业实践教学的现状及存在的问题}

\section{1 缺乏科学的实践教学体系}

布庸置疑, 任何教学活动都应具备完善的方案体系, 高校会计专业实践教学也不例外。会计学专业的发展潮流 要求教育工作者以人为本, 促进大学生的全面发展, 尤其 是实践能力和创新能力的提高。学生实践能力与创新能力 的形成来自于学生自身亲力亲为的实践感受, 来自于模拟 现实工作环境场景下手与脑的自如配合以及知识的灵活迁 移。这些活动的实现, 都要依托于科学合理的实践教学体 系设计与安排, 而这恰恰是现有会计实践教学体系薄弱之 所在。现阶段, 我国高校财会专业的教师水平良莠不齐, 各学校的会计实践教学也存在很大的差距, 从整体上来看, 仍然缺乏一套完整的、科学的会计实践教学体系, 这使得 大多数高校忽视自身的实际情况, 盲目模仿其他会计实践 
教学水平较高的高校, 导致会计专业学生的理论基础难以 和实践工作对接, 让会计实践教学流于表面形式。

2.2 实践教学方式与内容与实际有差距, 社会实践环节薄 弱

由于条件限制当前很多高校会计实践教学仍以校内模 拟为主。课程理论学习完之后配套的模拟实训多以在教室 或实验室通过模拟企业环境的方式, 采用手工或上机操作 方式进行练习，与企业会计工作流程差距较大。在具体的 实训内容上, 也仅仅是一些企业模拟资料, 无法模拟企业 的实际工作情况, 上述原因导致会计实践教学内容总是滞 后于企业实际。

同时校外实习的社会实践环节建设方面也往往很薄 弱, 课时安排少, 甚至不予安排。虽然某些院校在学生毕 业前的最后一学期安排有社会实践环节, 但由于不能够很 好地统一组织安排, 大多数是放任学生自己安排实践的方 式和内容, 导致一些学生并不能好好地把握机会或根本无 法找到合适的实习单位; 有些学生即使自己找到了实习单 位, 实习单位往往又以会计部门的特殊性为借口, 不给实 习学生接触实际业务的机会, 或者只能够看不能够实际操 作，学生根本不能接触到会计专业的实质内容。

\section{3 缺乏具有实践经验的会计教师}

目前, 各高校会计类专业教师, 尤其是青年教师大都是 从学校毕业后就走上讲台, 没有实际工作经验, 缺乏操作 真实经济活动的经历, 因此在会计实践教学上缺少举一反 三、灵活应用、列举演示规范操作实例的能力。很多教师 常年从事会计的课堂教学工作，与单位的会计实际工作脱 节, 对国家的方针、政策变化缺乏了解, 实践知识和实践 经验得不到及时更新。同时，由于会计专业招生规模大， 教学任务繁重, 在组织上、时间上没有相应的安排和保证, 也客观上造成了教师脱离实践的情况。

\section{3. 基于执业能力培养的会计学专业实践教学体系的 构建与实施注意事项}

\section{1 实践教学体系改革}

与市场对会计人员素质要求的不断提高相适应, 高校 的会计学教育方向特别是会计本科教育逐步向能力导向型 转变, 在进行理论知识传授的同时, 学生的实践创新能力 培养在教学体系中的地位越来越突出。在会计学专业建设
中, 如何完善会计实践教学体系、整合会计系列实验课程 的教学内容、研究会计系列实验课程的教学模式, 使学生 在有限的时间内掌握会计的基本理论和方法与技能, 提高 创造性地应用会计信息进行经济决策的能力, 显得越来越 重要。笔者所在院校在二十余年专业建设的探索中, 本着 “培养应用型人才” 的办学宗旨形成了一套较为完整、系 统的基于执业能力培养的会计学专业实践教学体系（见图 1)。

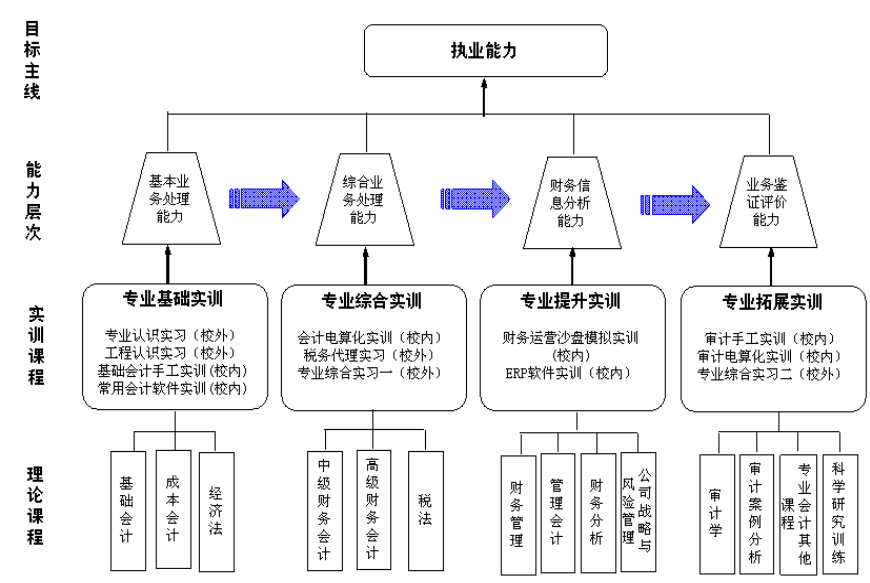

图 1 基于执业能力培养的会计学专业实践教学体系

该教学体系特点体现在:

（1）明确了以 “培养执业能力” 为主线的实践教学理念, 搭建了 “校内实训” 和 “校外实习基地” 两个实践教学平 台。

（2）改革实践课程体系和内容，整合优化为 “会计执业能 力训练”一条目标主线, “基本业务处理、综合业务处理、 财务信息分析和业务鉴证评价” 四个能力层次，“专业基础 实训、专业综合实训、专业提升实训和专业拓展实训” 四 个教学模块的会计学专业实践教学体系。

（3）现了单项实训与综合实训相结合; 校内实训与校外实 训相结合; 手工实训与电算化实训相结合的多维度、立体 化，四年连续、互补、递进式的实践教学新模式。

\section{2 加强师资队伍建设}

会计学专业强调实践教学的重要性, 但教师却缺乏实 践经验, 这无疑成为制约会计专业实践教学发展一个重要 瓶颈。故应想方设法提高教师的实践能力和综合素质, 这 一目标可以通过以下几种途径实现: 首先, 鼓励专业教师 从事实践工作，学校要在政策上给予支持和保障，允许专 
职老师到会计师事务所、企业进行专业培训、挂职锻炼, 使他们及时了解会计实务的发展情况, 在为社会提供专业 服务的同时，也可以切实提高教师的实践能力和技能水平， 为会计实践教学的顺利发展铺平道路。其次, 加强与实务 界的交流。鼓励教师有目的地参加一些专业研讨、培训, 经常与实务界人士进行交流, 深入业务调研及实践, 从企 业中学习掌握会计业务处理技巧和分析业务的能力, 把握 企业会计实务操作的前沿动态。最后, 引进具有丰富实践 经验的实务界会计人才, 充实实践教学队伍, 也有利于会 计理论与实践教学的共同提高。或从企业或会计师事务所 聘请有丰富实际工作经验的高级财会人员对学校教师进行 培训或讲座, 拉近实践教学与实际的距离。学校还可以与 企业制订校企合作计划, 让老师与企业进行长效的 “产学 研”合作，实现校企双方共赢。

\section{3 加强校外实习基地的建设}

实践教学要求学生近距离接触会计实务和管理环境。 因此, 高校通过校企合作共建校内与校外结合、课内与课 外结合的实践教学基地很有必要。笔者所在学院与当地注 册会计师协会联合共建人才培养基地，利用协会服务于当 地所有会计师事务所的平台，有效解决了单个企业容纳不 了所有实习学生的问题, 将学生输送至不同会计师事务所 进行实习。学生在事务所实习过程中, 可以接触到不同行 业的经济业务, 了解审计工作流程, 并且有事务所经验丰 富的审计人员进行指导, 为学生搭建了很好的理论与实践 相结合的操作演练平台, 实现了学生与企业零距离对接。

\section{4 重视实验课程教材的编写}

目前关于会计的一些教材或多或少地存在滞后现象, 书本知识陈旧, 最新业务发展很难及时反映在教材中, 书 本上学的知识在企业中用到的很少, 这都说明目前使用的 实践教材缺少实用性。因此实践课程教师应尽可能采用自 编教材或自编实训手册, 并根据自己在实践中收集到的企 业最新案例不断补充到每年度的实习课程中, 让学生更加 近距离的了解企业日常经济业务。在编写教材的时候, 还 可以邀请企业的实务人员参与其中，保证教材案例的合理 性与真实性。

\section{5 完善会计实践教学体系的监督和评价机制}

会计实践环节需要配备专门的教学督导, 对实践教学
教师的教学计划, 实践方案, 实践过程进行抽查和监督。 并定期对实验成果进行验收, 并进行存档记录。

另外, 为了会计专业实践教学的发展, 还要建立对学生的 综合考评体系, 考核会计专业实践教学的各个环节。综合 考评体系必须贯穿整个大学四年的实践课程体系中。考评 体系需要综合考虑课内实训课程考核、校外综合实训考核、 社会实践考核等多方面内容。在考核体系中, 应注重以过 程为中心, 评价学生平时表现与实践效果, 设计根据学习 与实践过程综合打分的有效、合理考核体系。

\section{4. 结语}

如何培养高水平、高层次的创新型、复合型会计应用 人才, 推动院校会计专业的持续发展是会计专业实践教学 的永远不会结束的问题。会计专业实践教学改革的方向应 是努力达到实践教学目标, 培养出符合社会会计人才需求 的学生。也只有不断通过对实践教学体系的改革与创新, 才能让会计专业实践教学发展的更好。

\section{参考文献(References)}

[1] Wang Yuan, Discussion on the Teaching Reform of Accounting Practice, Science and Technology Innovation Herald, vol. 32, pp. 123, 2013.

[2] Zhao Lin, Design and Evaluation of Accounting Professional Practice Teaching System Based on the Connotation Type Development, Commercial Accounting, vol. 8, pp. 124-125, 2013.

[3] Chen Yue and Zhang Xiaofang, Literature review on Accounting Practice Teaching, Education Teaching Forum, vol. 32, pp. 84-85, 2014.

[4] Li Yuping and $\mathrm{Li}$ Ting and Wang Ruixiao, Cooperation Research about Accounting Practice Teaching and the Occupation Development, Communication of Finance and Accounting, vol. 10, pp. 46-48, 2014.

[5] Wang Xiaoling, Discussion on the practical teaching system of accounting in Colleges and Universities, Journal of Inner Mongolia University of Finance and Economics, vol. 1, pp. 118-19, 2015. 